\title{
生体系をモデルとした電子伝達反応 ーフェレドキシンモデルを中心に一
}

\author{
井上博

\begin{abstract}
Electron-transfer Reactions Using a Model for an Electrontransfer Carrier in Biological Systems - Ferredoxin Model.
\end{abstract}

夫*

Hiroo INOU E*

\begin{abstract}
This review describes that the synthetic $4 \mathrm{Fe}-4 \mathrm{~S}$ cluster, which is a model compound for an active center of ferredoxin in biological systems, exhibits a prominent function as an electron-transfer carrier or an active site in various chemical oxidation-reduction reactions. The designed reactions using the synthetic $4 \mathrm{Fe}-4 \mathrm{~S}$ cluster are as follows : the reduction of acridinium salt, $\alpha-$ diketone, and $m$-dinitrobenzene with benzenethiol, the reductive cleavage of $\alpha$-isobutylthiodeoxybenzoin with 1-benzyl-1,4-dihydronicotinamide, the reduction of aromatic ketones, aldehydes, esters, and protons with carbanions such as $n$-butyllithium and phenyllithium, and the activation of hydrogen and the hydrogenation of olefins with the phenyllithium $/ 4 \mathrm{Fe}-4 \mathrm{~S}$ cluster system. Furthermore, the function of thiamine coenzyme in pyruvate oxygenase is mimiced and applied to the reduction of $4 \mathrm{Fe}-4 \mathrm{~S}$ cluster using thiazolium salt as a model compound.
\end{abstract}

\section{1. はじめに}

電子伝達反応とは，ある物質または系を介して電子供 与体から電子受容体へ電子を移していく反応のことであ る。この反応は酸化還元を触媒的に効率よく進めるだけ でなく，ある場合には，電子伝達体が電子供与体または 受容体を活性化して不可能な反応を可能にすることもあ り, 反応機構的に，また合成化学上重要である。その電 子伝達の仕組みは反応の種類によりいろいろ異なるが, 電子伝達体の酸化状態の変換機能や電子供与体または受 容体の酸化還元中間体の反応性を利用して，これまでに 多くの反応が組み立てられてきた。例えば，酸化還元の 単反応を触媒系に導いたワッカー反応1)，遷移金属の原 子価変換を利用した諸種の有機金属反応 ${ }^{22}$, ラジカル中 間種の酸化還元を経由する触媒反応 ${ }^{2}, \mathrm{~S}_{\mathrm{RN}}$ 反応の上うに, 一電子移動で誘起される二重活性化反応 ${ }^{3)}$, 光や電極を

* 大阪府立大学工学部応用化学教室

* Department of Applied Chemistry, College of Engineering, University of Osaka Prefecture
利用する電子伝達反応4) などはいずれもその代表的な反 応であり, それぞれについて, 膨大な研究がなされてい る。特に, 最近では, 生体の酸化還元系に関心がもたれ, その電子伝達系を構成する機能物質を人工的に開発し， 触媒として化学反応に応用しようとする研究が盛んに行 われている。

このような背景のもとで，筆者らは，生体のヒドロゲ ナーゼやニトロゲナーゼ反応において, 電子伝達体と して中心的な働きをする非へム鉄蛋白 Clostridium ェレドキシンに注目し，この生体機能を化学反応に応 用し, 新しい型の電子伝達触媒を生み出す目的で, モデ ル化合物としての立方型の鉄-硫黄クラスター $(4 \mathrm{Fe}-4 \mathrm{~S}$ クラスターと略記）を用いた電子伝達反応やその関連反 応の研究を展開している。そして, 鉄イオンが集合して クラスター構造をとると, 単核錯体より強い還元力が現 われること, また電子の蓄積と放出が円滑に進み, 酸化 と還元を分離する機能が現われることなど，クラスター 構造に由来する優れた電子伝達特性を見出している。本 稿では, この合成 $4 \mathrm{Fe}-4 \mathrm{~S}$ クラスターを用いた電子伝達 反応を中心に，ピルビン酸代謝系をモデルとした反応に ついて，筆者らの仕事を紹介し，その電子伝達機能を追 


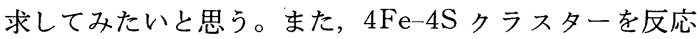
サイトとして利用した水素化反応についても, 生体機能 材料の有機反応への応用例として触れることにする。

\section{2. $8 \mathrm{Fe}-8 \mathrm{~S}$ 型フェレドキシンとそのモデル化合物}

本論に入る前に,フェレドキシンおよびそのモデル化合 物について，概略を述べておく。Clostridium フェレド キシンはバクテリアに含まれる分子量 6,200 の鉄-硫黄 蛋白であり，蛋白鎖は 55 個のアミノ酸から構成されて いる ${ }^{6)}$ 。その蛋白鎖には，8個のシスティン残基が存在 し, 2 個の $\mathrm{Fe}_{4} \mathrm{~S}_{4}$ 中心の各鉄イオンと配位結合している (図 1)。このフェレドキシンは $390 \mathrm{~nm}$ に吸収を示し, $-410 \mathrm{mV}$ の酸化還元電位 $\left(\mathrm{E}_{0}\right)$ )をもち, 生体ではピル ビン酸塩の酸化過程に関与している 型フェレドキシン $\left(\mathrm{Fd}_{\mathrm{ox}}\right)$ はピルビン酸塩を酸化して還 元型フェレドキシン $\left(\mathrm{Fd}_{\mathrm{red}}\right)$ となり(式1), 生じた $\mathrm{Fd}_{\mathrm{red}}$ は空素や亜硝酸イオンをアンモニウムイオンに（式 2), プロトンを水素に（式 3 ), 炭酸ガスをギ酸に（式 4) それぞれ還元するといわれている。(式 1 ) の反応にお いて, ピルビン酸塩のアシル残基は酸化還元に共役して $\mathrm{CoA}-\mathrm{SH}$ と反応し, CoA-SAc に変わる。また, ピルビ ン酸塩の他に, 水素もヒドロゲナーゼの存在下で $\mathrm{Fd}_{\mathrm{ox}}$ を還元する (式 5 )。

$$
\begin{array}{r}
\mathrm{CH}_{3} \mathrm{COCOO}^{-}+\mathrm{CoA}-\mathrm{SH}+\mathrm{Fd}_{\mathrm{ox}} \rightleftharpoons \\
\quad{\mathrm{CoA}-\mathrm{SCOCH}_{3}+\mathrm{CO}_{2}+\mathrm{Fd}_{\text {red }}}^{\longrightarrow} \\
\mathrm{Fd}_{\text {red }}+\mathrm{NO}_{2}^{-} \stackrel{\mathrm{H}^{+}}{\longrightarrow} \mathrm{Fd}_{\mathrm{ox}}+\mathrm{NH}_{4}^{+} \\
\mathrm{Fd}_{\mathrm{red}}+2 \mathrm{H}^{+} \longrightarrow \mathrm{Fd}_{\mathrm{ox}}+\mathrm{H}_{2} \\
\mathrm{Fd}_{\text {red }}+\mathrm{CO}_{2} \stackrel{\mathrm{H}^{+}}{\longrightarrow} \mathrm{Fd}_{\mathrm{ox}}+\mathrm{HCO}_{2}^{-} \\
\mathrm{Fd}_{\mathrm{ox}}+\mathrm{H}_{2} \stackrel{\text { Hydrogenase }}{\longrightarrow} \mathrm{Fd}_{\text {red }}+2 \mathrm{H}^{+}
\end{array}
$$

このフェレドキシンの活性部位は $\mathrm{Fe}_{4} \mathrm{~S}_{4}$ 中心であること から, 蛋白部分を単純なチオラート配位子に変えた $4 \mathrm{Fe}-$ $4 \mathrm{~S}$ クスターを一般に・ェレドキシンモデルと呼んで

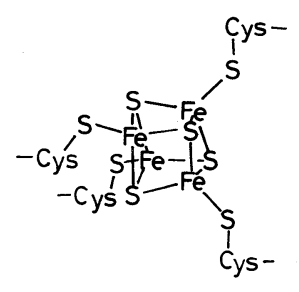

Active site of ferredoxin

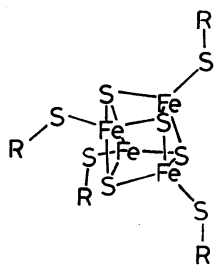

Ferredoxin model
いる（図1）。このモデル錯体は Holm らのグループに より初めて合成され，1973 年にその合成法やX線解析の 結果が報告された7)。合成は, (式 6 )の経路にしたがっ て, 脱気条件下で連続的に行われる。また，4個のチオ

$$
\begin{gathered}
4 \mathrm{FeCl}_{3}+12 \mathrm{NaSR} \longrightarrow \\
\begin{array}{c}
\stackrel{4 \mathrm{NaSH}+4 \mathrm{NaOMe}(\mathrm{SR})_{3}+12 \mathrm{NaCl}}{\longrightarrow} \mathrm{Na}_{2}\left[\mathrm{Fe}_{4} \mathrm{~S}_{4}(\mathrm{SR})_{4}\right] \\
+
\end{array} \\
\stackrel{\mathrm{RSSR}+6 \mathrm{NaSR}}{2 n-\mathrm{Bu}_{4} \mathrm{NBr}} \longrightarrow\left(n-\mathrm{Bu}_{4} \mathrm{~N}_{2}\left[\mathrm{Fe}_{4} \mathrm{~S}_{4}(\mathrm{SR})_{4}\right] \quad(6)\right.
\end{gathered}
$$

ラート配位子はより酸性度の高いチオール類 $\left(\mathrm{R}^{\prime} \mathrm{SH}\right)^{8)}$ および親電子試薬 $(\mathrm{YX})$ (たとえば， $\left.\mathrm{CH}_{3} \mathrm{COCl}\right)^{9)}$ によ り置換されるので（式 7,8 ), この置換反応を利用して 末端配位子を種々変換することができる。この直接法お

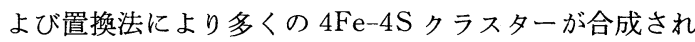
ている。

$$
\begin{aligned}
& {\left[\mathrm{Fe}_{4} \mathrm{~S}_{4}(\mathrm{~S}-t-\mathrm{Bu})_{4}\right]^{2-}+\mathrm{nR}^{\prime} \mathrm{SH} \rightleftharpoons} \\
& \quad\left[\mathrm{Fe}_{4} \mathrm{~S}_{4}(\mathrm{~S}-t-\mathrm{Bu})_{4-\mathrm{n}}\left(\mathrm{SR}^{\prime}\right)_{\mathrm{n}}\right]^{2-}+\mathrm{n} t-\mathrm{BuSH}
\end{aligned}
$$

$$
\begin{aligned}
& {\left[\mathrm{Fe}_{4} \mathrm{~S}_{4}(\mathrm{SR})_{4}\right]^{2-}+\mathrm{nYX} \longrightarrow} \\
& {\left[\mathrm{Fe}_{4} \mathrm{~S}_{4}(\mathrm{SR})_{4-\mathrm{n}}\left(\mathrm{SR}^{\prime}\right)_{\mathrm{n}}\right]^{2-}+\mathrm{n} t-\mathrm{BuSH}} \\
& \quad \mathrm{n}=1-4
\end{aligned}
$$

$\left[\mathrm{Fe}_{4} \mathrm{~S}_{4}(\mathrm{SR})_{4}\right]^{2-}$ はフェレドキシンに似た立方型の構 造をとって招り(図 1$)^{10)}, \mathrm{Fe}_{4} \mathrm{~S}_{4}$ 中心は型式的には 2 個 の鉄 (II) イオンと 2 個の鉄 (III) イオンとから構成さ れている。しかし, 害際には, 鉄イオンは等価で, $2.5+$ の酸化状態をとることがメスバウアースペクトルの測定

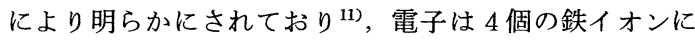
非局在化していると考えられる(図 2)。この $\mathrm{Fe}_{4} \mathrm{~S}_{4}$ 中心 には一電子をたは二電子を導入することが可能であり, 2-/3-および3-/4-の変換を行う。配位子が電子吸引性で あるほど電位はより正の值をとり，2-/3-変換における $\mathrm{E}_{1 / 2}$ 值 $(\mathrm{DMF})$ と $\mathrm{R}$ の置換基定数, $\mathrm{Taft} \sigma^{*}$ 值 $(\mathrm{R}=t-\mathrm{Bu}$, $i$ - Pr. $n$ - Pr, Et, Me, $\left.\mathrm{CH}_{2} \mathrm{Ph}\right)$ ，または Hammett $\sigma_{\mathrm{p}}$ 值 $\left(\mathrm{R}=p-\mathrm{C}_{6} \mathrm{H}_{4} \mathrm{X}: \mathrm{X}=\mathrm{Me}, \stackrel{+}{\mathrm{H}}, \mathrm{NMe}_{3}\right)$ との間には, (式 9, 10 )のような直線関係が成立すると報告されている ${ }^{12)} 。$

$$
\begin{aligned}
& \mathrm{E}_{1 / 2}(\mathrm{~V})=0.411 \sigma^{*}-1.3 \\
& \mathrm{E}_{1 / 2}(\mathrm{~V})=0.295 \sigma_{\mathrm{p}}-1.04
\end{aligned}
$$

Fig. 1

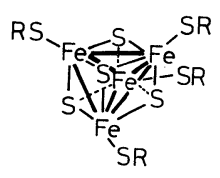

Fig. 2 
また，クラスターの電位は環境の影響を受け，水の溶媒 和，あるいはプロトン供与性分子の水素結合により正の 方向に移る。例えば, $\mathrm{R}=\mathrm{CH}_{2} \mathrm{CH}_{2} \mathrm{OH}$ のクラスターで は, $\mathrm{E}_{1 / 2}(\mathrm{SCE})$ 值は $80 \mathrm{vol} \% \mathrm{DMSO}$-水溶液で -1.05 $\mathrm{V}, 40 \mathrm{vol} \% \mathrm{DMSO}$-水溶液で $-0.89 \mathrm{~V}$, 水溶液で -0.75 $\mathrm{V}$ と順に高くなる ${ }^{13)}$ 。また， $\mathrm{R}=\mathrm{C}_{6} \mathrm{H}_{4}-\mathrm{O}-\mathrm{OH}$ では，配 位子と $\mathrm{OH}$ 基の分子内水素結合により, $\mathrm{E}_{1 / 2}(\mathrm{SCB})$ は $\mathrm{R}=\mathrm{Ph}$ に比べて $0.15 \mathrm{~V}(2-/ 3-), 0.22 \mathrm{~V}(3-/ 4-)$ 正の方 向に移る14)。さらに，R=Z-Cys-Gly-Ala-OMeのクラ スターでは, $\mathrm{E}_{1 / 2}$ ( $\mathrm{SCE}$ ) 值は $303 \mathrm{~K}$ での $-1.00 \mathrm{~V}$ から $233 \mathrm{~K}$ での $-0.85 \mathrm{~V}$ と正の方向に移り, これは AlaNH と Cys の水素結合 (NH…S) に起因すると示唆されてい る ${ }^{15)}$ 。このように, $\mathrm{Fe}_{4} \mathrm{~S}_{4}$ 骨格の電子は非局在化してい ると考えられ，その酸化還元電位は低く，末端配位子や 環境の影響を受ける。

\section{3. 電子伝達反応}

前述した合成 $4 \mathrm{Fe}-4 \mathrm{~S}$ クラスターの性質をもとに, 筆 者らは $4 \mathrm{Fe}-4 \mathrm{~S}$ クラスターの電子伝達機能および反応性 に関して, 次のことを期待し，その機能を調べるととも に，諸種の反応に応用した。

1）酸化状態の変換機能。電子伝達系の構成には, 酸 化状態の変換機能をもつ電子伝達体が必要である。 $4 \mathrm{Fe}-$ $4 \mathrm{~S}$ クスターは 2-,3-, 4-の酸化状態をとり得るので, この酸化状態の変換を利用して諸種の電子伝達系を構成 することが可能であろう。

2) クラスター構造に由来する還元能。電子供与体お よび受容体が $\mathrm{Fe}_{4} \mathrm{~S}_{4}$ 中心に接近した際, 図3に示すように, $\mathrm{Fe}_{4} \mathrm{~S}_{4}$ 骨格内で電子の偏りが生じ, その状態に電子が導入 され, 同時に, $\mathrm{Fe}_{4} \mathrm{~S}_{4}$ 中心から電子が押し出されるという 伝達系が構成されると, 還元力は増大する。4-レベルの $4 \mathrm{Fe}-4 \mathrm{~S}$ クラスター（4 個の鉄 (II ) イオンからなる) の 場合には，還元力の増大により鉄 (I) 状態に近い還元 機能が現われるかもしれない。

3）酸化と還元の分離。別々の鉄サイトからの電子の 導入と放出は電子供与体の酸化と電子受容体の還元を分

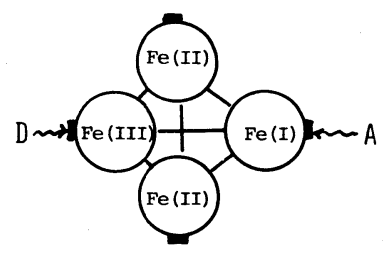

D: Electron donor A: Electron acceptor

Fig. 3
離することに役立つであろう。

4）多電子移動。2-/4-変換により二電子還元または 酸化が起こるであろう。

5）反応サイト。末端配位子は置換反応を行うので, この配位サイトを反応場として用いることが可能であろ う。しかも， $\mathrm{Fe}_{4} \mathrm{~S}_{4}$ 中心の電子状態を変えることにより， 配位サイトでの反応を制御することができるかもしれな い。

なお，以下の反応では，ベンゼンチオラート配位子を もつ $4 \mathrm{Fe}-4 \mathrm{~S}$ クスター（1）を（式 6）の直接法によ り合成し，使用した。このクラスター 1 は mp 190 191 ${ }^{\circ} \mathrm{C}$ 黒色結晶で, $\mathrm{MeCN}, \mathrm{DMF}, \mathrm{DMSO}$ などの有機溶 媒に可溶である。DMF 中での可視吸收スペクトルは 457 $\mathrm{nm}\left(\varepsilon: 1.77 \times 10^{4}\right)$ に吸収を示し, 酸化還元電位 $\left(\mathrm{E}_{1 / 2}\right.$, DMF) は 2-/3-変換が-1.039 V, 3-/4-変換が-1.748 $\mathrm{V}$ である ${ }^{12)}$ 。

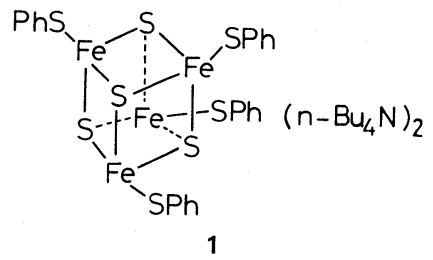

3. 1. $4 \mathrm{Fe}-4 \mathrm{~S}$ クラスタ一の酸化により誘起される電 子伝達反応 チオラート類はクラスター 1 を還元する ことはできないが，電子受容体で 1 を酸化すると，配位 子から電子が移行し, ジフェニルジスルフィドが生成す る。したがって，電子供与体としてチオールまたはチオ ラート類を用いる場合には, 電子受容体によるクラスタ 一の酸化が引き金となって電子伝達系が形成される。べ ンゼンチオラート/クラスター1系は塩化 10-メチルアク リジニウムを触媒的に還元し, 定量的に 10,10'-ジメチ ルビアクリダンを与える(式 12$)^{16)}$ 。その際, ビアクリ ダンに対応する量のジフェニルジスルフィドが生成する。 クラスター 1 が存在しないと, ベンゼンチオラートがア クリジニウム塩の 9 位に付加した生成物が定量的に得ら れる(式 11 )。アクリジニウム塩の還元は, 電子供与体 としてのチオラートが存在しなくても起こるので, (式 12 ）の反応はアクリジニウム塩による酸化が引き金と なる電子伝達系と考えられる。その他の反応例を（式 13

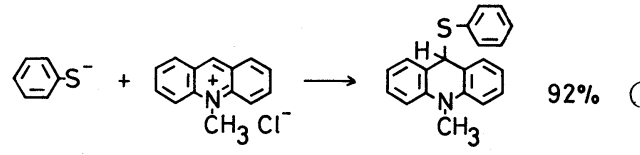




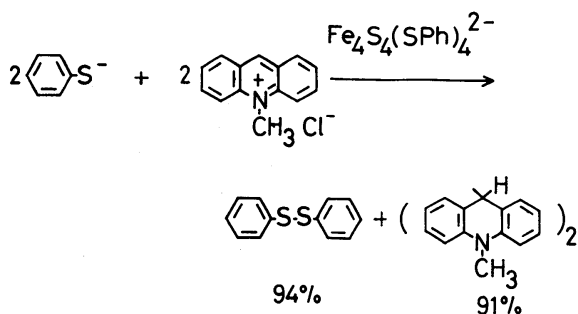

$\mathrm{MeOH}, 8-12^{\circ} \mathrm{C}, \mathrm{Ar}$

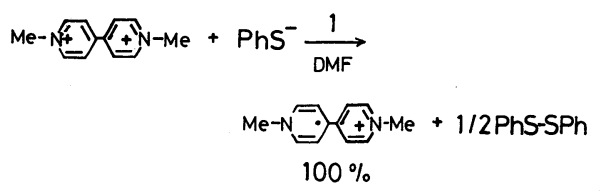

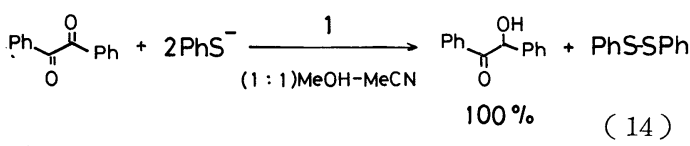$$
\widehat{\mathrm{O}}_{\mathrm{NO}_{2}}^{\mathrm{NO}_{2}}+6 \mathrm{PhS}^{-} \frac{1}{\stackrel{\mathrm{O}_{(1: 1) \mathrm{MeOH}-\mathrm{MeCN}}^{\mathrm{NH}}}{\longrightarrow}+3 \mathrm{PhSSPh}+2 \mathrm{H}_{2} \mathrm{O}}
$$

～ 15 ）に示す。 $m$-ジニトロベンゼンの場合には， 1 個 のニトロ基のみが触媒的にアミノ基に還元される ${ }^{17)}$ 。ま た，これらの反応において，クラスター1 は反応後回収 される。 $\mathrm{NADH}$ モデルとして知られている 1-ベンジル -1, 4-ジヒドロニコチン酸アミド (BNAH) を電子供与体 として用いた場合にも, 同様に電子伝達系が形成される。

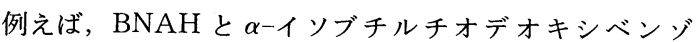
インのベンゼン溶液に, 1 を分散させ, $\mathrm{Ar}$ 下, $80^{\circ} \mathrm{C}$ で 加熱すると, 炭素一硫黄結合の還元的切断により, デオ キシベンゾインが生成する (式 16$)^{18)}$ 。チオデオキ シベンゾインが存在しない系では, BNAH は 1 と酸化 還元を行わない。BNAH から得られる二量体(式16)を 純粋に単離することはできなかったが，ジイソブチルジ

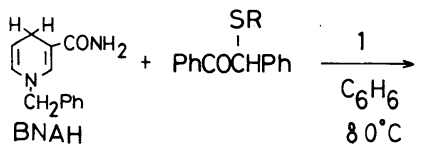

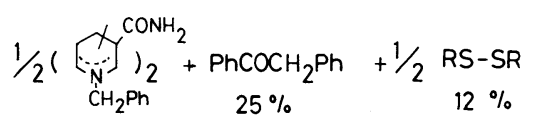

スルフィドがデオキシベンゾインの約 $1 / 2$ モル量生成し ていることから, 恐らく（式 17～19）の反応が起こっ ていると考えられる。

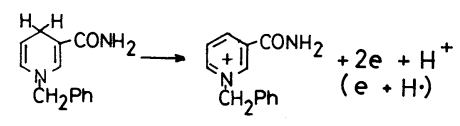

$$
\begin{aligned}
& \text { SR } \\
& \mathrm{PhCOC} \mathrm{HPh}+\underset{\left.(\mathrm{e}+\mathrm{H} \cdot)^{+}\right)}{2 e} \longrightarrow \\
& \mathrm{PhCOCH}_{2} \mathrm{Ph}+\mathrm{RS}^{-}
\end{aligned}
$$

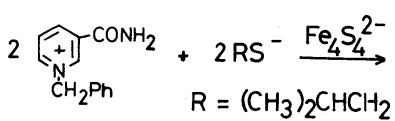

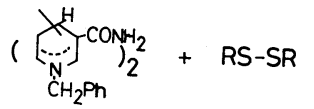

3. 2. $4 \mathrm{Fe}-4 \mathrm{~S}$ クラスターの還元により誘起される電 子伝達反応 基質の還元が 2-状態で起こらないときに は，2-/3-または 2-/4-変換を利用して電子伝達系を形 成することができる。クラスター 1 の還元電位は低いの で, 1 の還元には比較的強い還元剂が必要になる。2-/3変換には, 亚ジチオン酸ナトリウム, 水素化ホウ素ナト リウム，アセナフチレンのアニオンラジカル ${ }^{19)} ， 2-/ 4-$ 変換には, ナフタレンのアニオンラジカル ${ }^{20)}$ が用いられ, 窒素やその類縁化合物の電子伝達還元が試みられている。 また, 電子供与源として電極を用い, 電位を調節して 3または 4-状態にもっていくことができる。この方法で炭 酸ガス ${ }^{21)}$, イミン類 ${ }^{22)}$, プロトン ${ }^{23)}$ など, 興味ある化合 物の還元が行われている。筆者らは, カルバニオンが酸 化により二量化や不均化を行い，安定な化合物に変わる ことに着目し，また後述するように，生体系ではカルバ ニオン構造をとる活性アルデヒドが電子供与体となるこ とから, 電子供与体として, $n$-ブチルリチウム $(n-\mathrm{BuLi})$ やフェニルリチウム $(\mathrm{PhLi})$ を用いることにした。また, クラスター1はベンゼンやエーテルなどの溶媒に不溶で あるが, $n$-BuLi や PhLi で処理すると, 可溶になり, 均 一系で反応を行うことができるという利点もある。反応 は次のように行われた。すなわち, $n$-BuLi または PhLi のエーテル溶液を脱気し，Ar下でクラスター1を加え， $0{ }^{\circ} \mathrm{C}$ で 30 分間攪汼する。1を加えると, 反応液は直ち に黒色を呈し, 均一な溶液が得られる。この過程で, $n-$ BuLi またはPhLi は 1 を二電子還元し, 前者は不均化 により1-ブテンとブタン, さらに1-ブテンの異性化に 
よりシスーおよびトランス-2-ブテン，および二量化によ りオクタンに, 後者は二量化によりビフェニルに変換さ れる (式 20$)^{24)}$ 。過剩の $n-\mathrm{BuLi}$ または $\mathrm{PhLi}$ を用いて $2 \mathrm{CH}_{3}\left(\mathrm{CH}_{2}\right)_{2} \mathrm{CH}_{2}{ }^{-} \longrightarrow \mathrm{CH}_{3}\left(\mathrm{CH}_{2}\right)_{2} \mathrm{CH}_{3}$

$+\mathrm{CH}_{3} \mathrm{CH}_{2} \mathrm{CH}=\mathrm{CH}_{2}$

(cis- and trans- $\left.\mathrm{CH}_{3} \mathrm{CH}=\mathrm{CHCH}_{3}\right)+2 \mathrm{e}$ $2 \mathrm{CH}_{3}\left(\mathrm{CH}_{2}\right)_{2} \mathrm{CH}_{2}^{-} \longrightarrow \mathrm{CH}_{3}\left(\mathrm{CH}_{2}\right)_{6} \mathrm{CH}_{3}+2 \mathrm{e}$ $2 \mathrm{C}_{6} \mathrm{H}_{5}-\mathrm{C}_{6} \mathrm{H}_{5}-\mathrm{C}_{6} \mathrm{H}_{5}+2 \mathrm{e}$

この調整液をつくり, その溶液に Ar 下でカルボニル化 合物を加え, 室温で 20 時間反応させ, 還元生成物を追 跡してクラスター 1 の電子伝達機能を調べた。 $n$-BuLi/ 1 系によるフルオレノン $\left[\mathrm{E}_{1 / 2}(\mathrm{SCE}):-1.29,-1.95\right.$ $\mathrm{V}^{25)}$ の還元では, そのピナコールとヒドロールが生成 するが，収率は $n$ - $\mathrm{BuLi} / \mathrm{Fe}$ イオンのモル比に依存し， モル比が低いところでは一電子還元によりピナコール, モル比が高いところでは二電子還元によりヒドロールが 生成する (式 21$)^{24)}$ 。二電子還元が起こっていることは 反応後に重水を加えると, 重水素化ヒドロールが生成す ることから明らかである（式 22 ）。1の代わりに，塩化 鉄（III）を用いてこの反応を行うと, $n-\mathrm{BuLi} /$ 塩化鉄 (III) のモル比が高いところでは, ヒドロールがピナコー ルより多く生成するが, 反応後に重水を加えても重水素化 ヒドロールは得られない2 ${ }^{24)}$ このヒドロールは, $\mathrm{RMgX/}$ 塩化鉄(III)系によるケトン類の還元 ${ }^{26)}$ で示されるように, ブチルアニオンの $\beta$-脱離により生じたヒドリドがカル ボニル基に付加して生成すると考えられる。このヒドロ

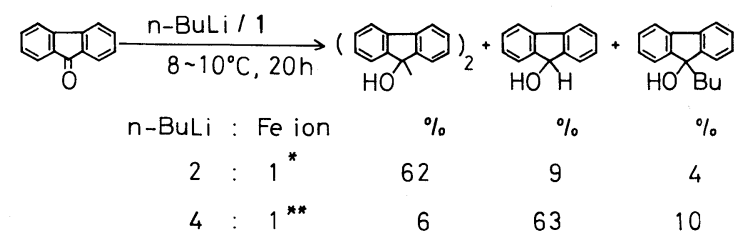

* $\mathrm{Bu}-\mathrm{Bu}(36 \%)$. ** BuH, Bu(-H). Ketone $/ \mathrm{Fe}=1$.

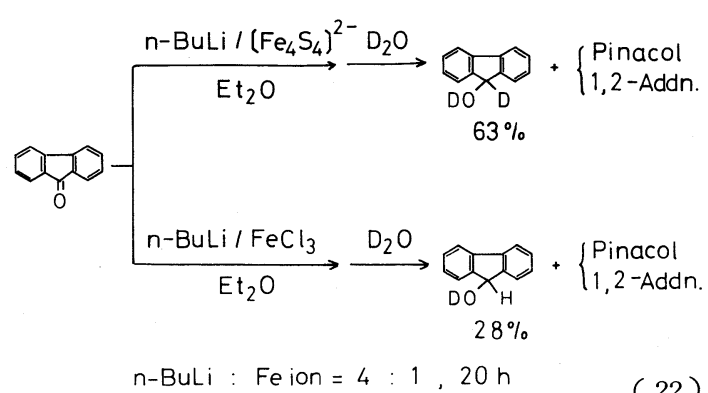

ールの生成挙動の違いはクラスター 1 が酸化と還元を効 率よく分離することを示している。その他のケトンやア ルデヒド類について行った結果をその還元電位とともに 表 1 に示しておく ${ }^{27)}$ 。表中の $\mathrm{E}_{1 / 2}(\mathrm{SCE})$ はいずれも $\mathrm{DMF}$ または $\mathrm{MeCN}$ 中での測定値である。 $n-\mathrm{BuLi}$ また は $\mathrm{PhLi} / 1$ 系の還元能は基質の還元電位が約 $-2.1 \mathrm{~V}$ 付 近（ 1 の還元電位より約 $0.3 \sim 0.4 \mathrm{~V}$ 低い）に限界があり, それより負の基質を還元することはできない。しかし， 鉄（II）の単核錯体で還元し得ない基質を還元する。ま た, 反応後, ジフェニルジスルフィドの存在下, ベンゼ ンチオールで処理すると, もとのクラスター 1 が回収さ れる。塩化鉄（III）との反応性の比較を表 2 に示す。表 の值はピナコール，ヒドロール，1,2-付加体の生成比率 を示したものである。塩化鉄 (III) の場合の還元種は $\mathrm{Fe}$ （I）錯体であるが，ブチルアニオンからのヒドリドの 移動によりヒドロールがかなり多く生成する。 $d l /$ meso 比は両者で大差は認められない。しかも, 塩基性条件下 でこれらのカルボニル化合物を電極還元したときの $d l /$ meso 比 $^{28)}$ に近い。

芳香族エステル類の還元では ${ }^{29)}$, 一電子還元ののちに 二量化した $\alpha$-ジケトンとその二電子還元生成物， $\alpha-$ 七 ドロキシケトンが生成するが，還元に無関係な副生成物 が生成するために, 収率はケトンやアルデヒド類の場合 に比べて低下する。一例を（式 23 ) に示す。塩化鉄 (III) の場合には基質に対して塩化鉄（III）のモル量を多くす

Table 1 The reduction of ketones $\left(\mathrm{R}^{1} \mathrm{COR}^{2}\right)$ with the $n$-BuLi/1 system ${ }^{\mathrm{a}}$.

\begin{tabular}{l|l|c|c|c|c}
\hline $\mathrm{R}^{1}$ & \multicolumn{1}{|c|}{$\mathrm{R}^{2}$} & $\mathrm{E}_{1 / 2}(\mathrm{~V})^{\mathrm{b})}$ & Pinacol (\%) & Hydrol (\%) & 1,2-Addn.(\%) \\
\hline $\mathrm{Ph}$ & $\mathrm{Ph}$ & $-1.83,-2.09$ & 57 & 9 & 6 \\
$\mathrm{Ph}$ & $\mathrm{Me}$ & $-1.87,-2.32$ & 57 & 0 & 12 \\
$\mathrm{Ph}$ & $\mathrm{H}$ & $-1.93,-2.51$ & 58 & 0 & 29 \\
$\mathrm{Me}$ & $\mathrm{CH}_{3}\left(\mathrm{CH}_{2}\right)_{8}$ & $<-2$ & \multicolumn{2}{|c}{ Aldol condn. } & \\
\hline
\end{tabular}

a) $n$-BuLi: Fe ion:Sub. $=(3-4): 1: 1$. rt, $20 \mathrm{~h}$.

b) T. J. Curphey, L. D. Trivedi, T. Layloff, J. Org. Chem., 39, 3831 (1974); L. Meites, P. Zuman, W. J. Scott, B. H. Campbell, A. M. Kardos, "Electrochemical Data", Part 1, A, 1974, pp. 272 and 332. 
Table 2 Comparison of the reactivity between 1 and $\mathrm{FeCl}_{3}$ in the reduction of aromatic ketones ( $\mathrm{PhCOR}$ ) with the $n$ - $\mathrm{BuLi} / 1$ or $\mathrm{FeCl}_{3}$ system ${ }^{\mathrm{a}}$.

\begin{tabular}{c|c|c|c|c|c|c}
\hline $\mathrm{R}$ & Fe-comp. & $n$-BuLi/Fe ion & Pinacol (\%) & Hydrol (\%) & 1,2-Addn. (\%) & dl/meso \\
\hline $\mathrm{Ph}$ & 1 & 2.7 & 76 & 16 & 8 & \\
$\mathrm{Ph}$ & $\mathrm{FeCl}_{3}$ & 3.6 & 0 & 90 & 10 & \\
$\mathrm{Et}$ & 1 & 3.7 & 80 & 0 & 20 & 1.9 \\
$\mathrm{Et}$ & $\mathrm{FeCl}_{3}$ & 3.7 & 36 & 64 & 0 & 2.4 \\
$\mathrm{Me}$ & 1 & 4 & 79 & 4 & 17 & 2.2 \\
$\mathrm{Me}$ & $\mathrm{FeCl}_{3}$ & 3.5 & 59 & 41 & 0 & 2.8 \\
$\mathrm{H}$ & 1 & 3.7 & 67 & 0 & 33 & 1.6 \\
$\mathrm{H}$ & $\mathrm{FeCl}_{3}$ & 3.0 & 87 & 13 & 0 & 1.9 \\
\hline
\end{tabular}

a) $\mathrm{Et}_{2} \mathrm{O}, \mathrm{rt}, 20 \mathrm{~h}$. Conversion $\%:>70 \%$. Pinacol $\%+$ Hydrol $\%+1,2-$ Addn. $\%=100 \%$. Fe ion : sub. $=1: 1$.

るか, あるいは濃度を濃くすると収率は増大する。(4: 1) $\mathrm{FeCl}_{3} / 1$ 混合系を用いると，還元効率は上がるが， ヒドリドの付加による第一アルコールの生成量が増大す る(式 24)。

$\mathrm{PhCOSPh} \frac{\text { 1) } n \text {-BuLi/Fe-comp. }{ }^{\text {a) }}}{\text { 2) } \mathrm{H}_{2} \mathrm{O}}$

$$
\stackrel{\stackrel{\mathrm{OH}}{\mathrm{P}}}{\mathrm{PhCOCOPh}+\mathrm{PhCOCH} h \quad(23)}
$$

$\begin{array}{lccccccc}\text { Fe-comp. } & n \text {-BuLi } & : & \text { Fe ion } & : & \text { Sub. } & \% & \% \\ 1^{\text {()) }} & 4 & : & 1 & : & 1 & 6 & 31 \\ 1^{\mathrm{d})} & 8 & : & 2 & : & 1 & 0 & 34(14)^{\mathrm{b})} \\ \mathrm{FeCl}_{3}{ }^{\mathrm{e})} & 4 & : & 1 & : & 1 & 0 & 27 \\ \mathrm{FeCl}_{3}{ }^{\mathrm{f}} & 12 & : & 3 & : & 1 & 23 & 45\end{array}$

a) $\mathrm{Et}_{2} \mathrm{O}, 10{ }^{\circ} \mathrm{C}, 20 \mathrm{~h}$. b) Yield of $\mathrm{PhCH}(\mathrm{OH}) \mathrm{C}(\mathrm{OH}) \mathrm{BuPh}$ Other products : c. d) $\mathrm{PhC}(\mathrm{OH}) \mathrm{Bu}_{2}(28,15 \%)$, e) $\mathrm{PhCOOBu}$ $(24 \%)$. $\mathrm{PhCOOH}(23 \%)$, f) $\mathrm{PhCOOH}(31 \%)$.

$\operatorname{RCOY} \underset{\mathrm{FeCl}_{3}-1}{\stackrel{\left.n-\mathrm{BuLi}^{\mathrm{a}}\right)}{\longrightarrow}} \mathrm{RCOCOR}+\mathrm{RCOCHR}$

$$
+\mathrm{RCH}_{2} \mathrm{OH}+\text { Others }
$$

$\begin{array}{lcrrrr}\mathrm{R} & \mathrm{Y} & \% & \% & \% & \% \\ \mathrm{Ph} & \mathrm{PhS} & 12 & 54 & 0 & 16 \\ \mathrm{C}_{7} \mathrm{H}_{15} & \mathrm{PhS} & 0 & 16 & 33 & 46 \\ \mathrm{Ph} & \mathrm{PhO} & 6 & 21 & 38 & 12\end{array}$

a) $n-\mathrm{BuLi} / \mathrm{FeCl}_{3} / 1 / \mathrm{Sub} .=8 / 1 / 0.25 / 1 . \mathrm{Et}_{2} \mathrm{O}, \mathrm{rt}, 20 \mathrm{~h}$.

このように，4個の鉄（II）イオンが集合した $4 \mathrm{Fe}-$ $4 \mathrm{~S}$ クラスターは, 単核の鉄 ( I ) 錯体に匹敵する還元力 を示し, カルバニオンの酸化とカルボニル化合物の還元 を分離する機能を発現する。これらの機能発現は, 図 3 に示すように, 電子供与体と受容体の接近により $\mathrm{Fe}_{4} \mathrm{~S}_{4}$ 中心で電子の偏りが生じ, 電荷を分離することに起因す るのかもしれない。Schrauzer らは以前に鉄（II）イオ
ンをグルコースで集合させた系がプロトンを水素に還元 することを見出し ${ }^{30)}$, 同じような電荷分離の機構を提出 しており, 集合体の一つの特徴として興味深い。

3. 3. プロトンの還元による水素の生成 生体内に おいて，フェレドキシンは 3-/1-変換によりプロトンを 二電子還元し，水素を生産するといわれている（式 3 ）。 この機能を化学的に再現するための研究が合成 $4 \mathrm{Fe}-4 \mathrm{~S}$

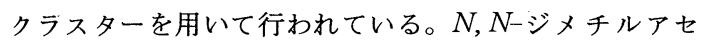
トアミド中, $\mathrm{Fe}_{4} \mathrm{~S}_{4}(\mathrm{SPh})_{4}^{3-}$ とベンゼンチオール（クラ スターに対して 240〜 480 倍モル使用) との反応では， 24 時間後, 化学量論量の $11 \sim 31 \%$ の水素が生成する こと ${ }^{31)}, \mathrm{Fe}_{4} \mathrm{~S}_{4}\left(\mathrm{SC}_{3} \mathrm{H}_{7}\right)_{4}^{4-}$ の構成成分である $\mathrm{Fe}$ (II) 塩, $\mathrm{S}^{2-}, n-\mathrm{C}_{3} \mathrm{H}_{7} \mathrm{~S}^{-}$(モル比; $1: 2: 6$ ) を無水メタノールに 溶かすと, $27^{\circ} \mathrm{C}$ で 24 時間後, 水素が $\mathrm{Fe}$ (II) イオンに 基づいて $20 \%$ 収率で生成すること ${ }^{32)}$, さらに, 電子供 与源として電極を用い, $(1: 1) \mathrm{MeOH}-\mathrm{THF}$ 中で 1 を 3-または 4-レベルに還元すると, 水素が発生すること ${ }^{23}$, などが報告されている。筆者らは, クラスター 1 を過剩

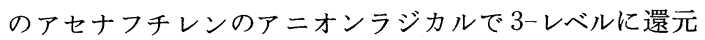
し, その系にAr 下ベンゼンチオールを加え, 水素の生 成量を調べたが, Holm らと同様に, 水素は $\mathrm{Fe}_{4} \mathrm{~S}_{4}$ 単位 当たり $0.16 \mathrm{~mol}$ 生成するのみであった（表 4 ）。ところ が, 対カチオンの $\mathrm{Na}^{+}$をクラウンまたは非環状グラウン エーテルで錯化すると, 水素の生成量は $4 \sim 5$ 倍増大す ることを見出した (式 25$)^{33)}$ 。次に, 前述の $\mathrm{PhLi} / 1$ 系

$\mathrm{Fe}_{4} \mathrm{~S}_{4}(\mathrm{SPh})_{4}\left(\mathrm{n}-\mathrm{Bu}_{4} \mathrm{~N}\right)_{2} \mathrm{Na} \rightleftharpoons\left[\mathrm{Fe}_{4} \mathrm{~S}_{4}(\mathrm{SPh})_{4}\left(\mathrm{n}-\mathrm{Bu}_{4} \mathrm{~N}\right)_{2}\right]^{1-}+\mathrm{Na}^{+}$

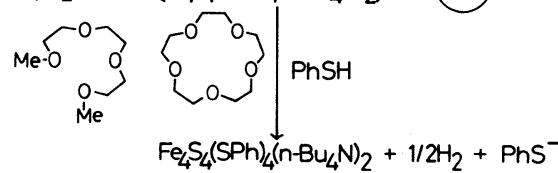

( 25 ) 
に, ベンゼンチオールを加えたところ，カルボニル化合 物の還元量にはほぼ近い量でプロトンが水素に還元され ること（図4), また水素発生後の系にアクリジンを加 え，9,9'-ビアクリダンとビフェニル量を定量したとこ ろ, 水素と $9,9^{\prime}$-ビアクリダンの生成量の和はビフェニ

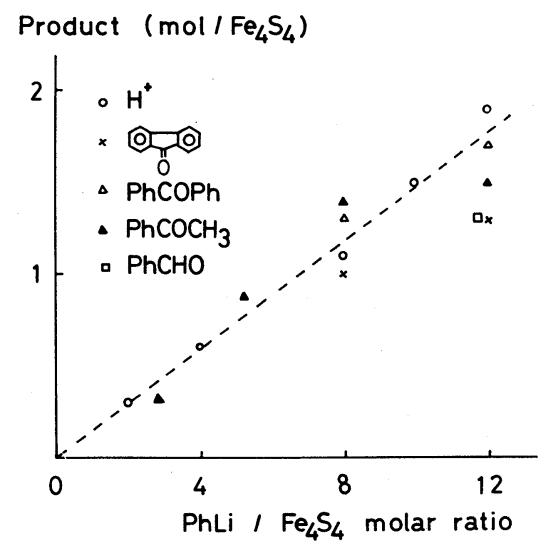

Fig. 4 Electron-transfer reduction of various substrates with the $\mathrm{PhLi} / 1$ system.

Table 3 The generation of hydrogen from protons of benzenethiol using the $\mathrm{PhLi} / 1$ system $^{\text {a) }}$

\begin{tabular}{r|c|c|c|c}
\hline \multirow{2}{*}{$\mathrm{PhLi}: 1$} & \multirow{2}{*}{ Solvent } & \multirow{2}{*}{$\mathrm{H}_{2}$} & \multicolumn{2}{|c}{$\mathrm{mol} / \mathrm{Fe}_{4} \mathrm{~S}_{4}$ unit } \\
\cline { 4 - 5 } & & & ${\left.\mathrm{HAc}-\mathrm{AcH}^{\mathrm{b}}\right)} \mathrm{Ph}-\mathrm{Ph}$ \\
\hline $8: 1$ & $\mathrm{Et}_{2} \mathrm{O}$ & 1.0 & 0.8 & 1.9 \\
$12: 1$ & $\mathrm{Et}_{2} \mathrm{O}$ & 1.8 & 0.7 & 2.6 \\
$10: 1$ & $\mathrm{Et}_{2} \mathrm{O}-\mathrm{HMPA}$ & 2.2 & 0.8 & 2.9 \\
\hline
\end{tabular}

a) 1:0.2 mmol in $\mathrm{Et}_{2} \mathrm{O}(8.8-11.2 \mathrm{ml})$ or $\mathrm{Et}_{2} \mathrm{O}(7 \mathrm{ml})-\mathrm{HMPA}(5 \mathrm{ml})$. $\mathrm{PhSH}: \mathrm{PhLi}=10: 1.0^{\circ} \mathrm{C}$, Ar. b) $\mathrm{HAc}-\mathrm{AcH} ; 9,9^{\prime}$-biacridan.
Table 4 The generation of hydrogen in various systems involving iron-complexes ${ }^{a}$ )

\begin{tabular}{l|c|c|c}
\hline \multirow{2}{*}{ System } & \multicolumn{3}{|c}{$\mathrm{mol}^{2} \mathrm{Fe}_{4} \mathrm{~S}_{4}$ unit } \\
\cline { 2 - 4 } & $\mathrm{H}_{2}$ & $\mathrm{HAc}-\mathrm{AcH}$ & $\mathrm{Ph}-\mathrm{Ph}$ \\
\hline $\mathrm{PhLi} / 1 / \mathrm{PhSH}(10 / 1 / 100)$ & 1.5 & 0.7 & 2.4 \\
$\mathrm{~A}^{*} / 1 / \mathrm{PhSH}_{(10 / 1 / 100)}$ & 0.16 & 0.26 & - \\
$\mathrm{PhLi} / \mathrm{FeCl}_{3} / \mathrm{PhSH}(3 / 1 / 30)$ & 0.09 & 0.36 & 0.9 \\
\hline
\end{tabular}

a) $0^{\circ} \mathrm{C}, \mathrm{Et}_{2} \mathrm{O} . \mathrm{HAc}-\mathrm{AcH}: 9.9^{\prime}$-biacridan. $\mathrm{A}^{\top}$ : Acenaphthylene anion radical.

ル量にほぼ一致することを見出した（表 3$)^{34)}$ 。9, 9 'ービ アクリダン量は反応後の $4 \mathrm{Fe}-4 \mathrm{~S}$ クラスターの酸化状態 を，ビフェニル量はプロトンと 1 の還元量を示すので, この結果は $\mathrm{PhLi}$ が 1 を介してプロトンを水素に還元し, 反応後のクラスターは 3-〜4-レベルをとることを示して いる。また, $\mathrm{PhLi}$ の使用量とビフェニルの生成量から， 約 50 60\%の PhLi が還元に使われ，残りはベンゼン チオールと直接反応し, ベンゼンに変わっていると見な される。プロトン源として，ベンゼンチオールの代わり に，酶酸やメタノールを用いたときにも，水素が発生す る $(\mathrm{PhLi} / 1=10$ の場合に，それぞれ 1.7 および $1.1 \mathrm{~mol} /$ $\mathrm{Fe}_{4} \mathrm{~S}_{4}$ 単位)。次に, 単核錯体としての塩化鉄（III）を用 いて同様の反応を行ったが，表4 亿示寸ように，鉄(I) 錯体の生成にもかかわらず水素の生成量はごくわずかで あることがわかった ${ }^{33)}$ 。のように，クラスター 1 はプ ロトンを二電子還元する電子伝達体として有効である。 プロトンを二電子還元すると，ヒドリドが中間に生成す ると考えられるので，このヒドリドの生成を確かめるた めに, $\mathrm{PhLi} / 1 / \mathrm{PhSH}$ 系に，ヒドリドをトラップする基 質を加えて生成物を追跡した（式 26$)^{33)}$ 。表 5 に示すよ

Table 5 The reduction of unsaturated compounds with the $\mathrm{PhLi} / 1 / \mathrm{PhSH}$ system ${ }^{\mathrm{a}}$.

$$
\mathrm{Fe}_{4} \mathrm{~S}_{4}(\mathrm{SPh})_{4}^{2-} \frac{\mathrm{PhLi}}{\mathrm{H}^{+}}\left[\mathrm{HFe}_{4} \mathrm{~S}_{4}(\mathrm{SPh})_{4}\right]^{\mathrm{n}-} \underset{\mathrm{Sub} .}{\stackrel{\mathrm{H}^{+}}{\longrightarrow} \mathrm{Fe}_{4} \mathrm{~S}_{4}(\mathrm{SPh})_{4}{ }^{\mathrm{m}-}+\mathrm{Sub}-2 \mathrm{H}}
$$

\begin{tabular}{|c|c|c|}
\hline \multirow{2}{*}{ Substrate } & \multicolumn{2}{|l|}{$\mathrm{mol} / \mathrm{Fe}_{4} \mathrm{~S}_{4}$ unit } \\
\hline & Reduction product & $\mathrm{H}_{2}$ \\
\hline None & & 1.8 \\
\hline $\mathrm{PhCOCH}_{3}$ & $\begin{array}{c}\mathrm{PhCH}(\mathrm{OH}) \mathrm{CH}_{3}(0.52), \mathrm{Ph}\left(\mathrm{CH}_{3}\right) \underset{1}{\mathrm{C}}-\mathrm{C}\left(\mathrm{CH}_{3}\right) \mathrm{Ph}(1.36) \\
\mathrm{HO} \mathrm{OH}\end{array}$ & 0.8 \\
\hline $\mathrm{CH}_{3}\left(\mathrm{CH}_{2}\right)_{8} \mathrm{COCH}_{3}$ & $\mathrm{CH}_{3}\left(\mathrm{CH}_{2}\right)_{8} \mathrm{CH}(\mathrm{OH}) \mathrm{CH}_{3}(0.99)$ & 0.7 \\
\hline $\mathrm{PhC} \equiv \mathrm{CPh}$ & cis $-\mathrm{PhCH}=\mathrm{CHPh}(0.5)$ & 0.8 \\
\hline
\end{tabular}

a) $\mathrm{Et}_{2} \mathrm{O}, \mathrm{Ar}, 0^{\circ} \mathrm{C}(2 \mathrm{~h}), \mathrm{rt}(4 \mathrm{~h}) . \mathrm{PhLi} / 1 / \mathrm{PhSH} / \mathrm{Sub}=12 / 1 / 120 / 50$. 
らに, 基質の添加により水素の生成量は減少し, その代 わりに, ヒドリドの付加生成物が得られた。2-ウンデカ ノンからそのヒドロールが, ジフェニルアセチレンから シスースチルベンのみが得られることは，親核性の鉄ヒドリド錯体が中間に生成していることを示唆する。水 素の生成反応は，スキーム1のように進むのであろう。 すなわち, クラスター 1 は $2 \mathrm{~mol} の \mathrm{PhLi} に よ り 二$ 電子 還元され，生じた4-レベルのクラスターはプロトンに二 電子を供与して中間に鉄 -ヒドリド錯体を生成し，同時

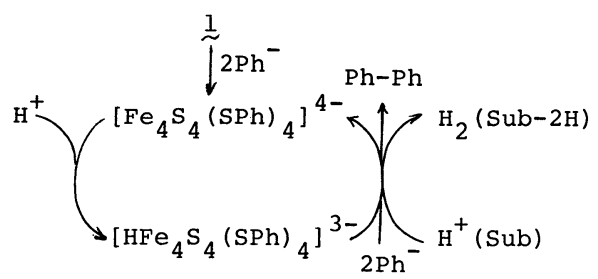

Scheme 1 Proposed pathway of hydrogen evolution.
に, PhLi から電子が供与され, ヒドリドは水素に変わ るという経路である。

3. 4. ピルビン酸代謝系をモデルとした電子伝達反応 ピルビン酸酸化酵素系に拉いて, ピルビン酸は酸化型フ ェレドキシンに電子を供与するが(式 1), この反応には, チアミン補酵索 (TPP) が触媒として関与し, スキーム 2 に示すように, TPP のチアゾリウム環がピルビン酸 塩と反応し, 脱炭酸を経て活性アルデヒドに変わり, こ のものがフェレドキシンに電子を供与するといわれてい る $^{6,35)}$ 。この酸化還元反応に共役してアシル残基は補酵 素 CoA-SH に移り, CoA-SAc の生成とともに, TPP が復元する。生じた還元型フェレドキシンは（式 $2 \sim 4$ ) の反応を行う。ここでは, この電子伝達系をモデルとし た反応について述べる。

TPP の代わりに, 合成チアゾリウム塩 (2) も塩基の 存在下でアルデヒド類と反応し, 中間に活性アルデヒド の生成を経てベンゾイン縮合を行うことはすでによく知

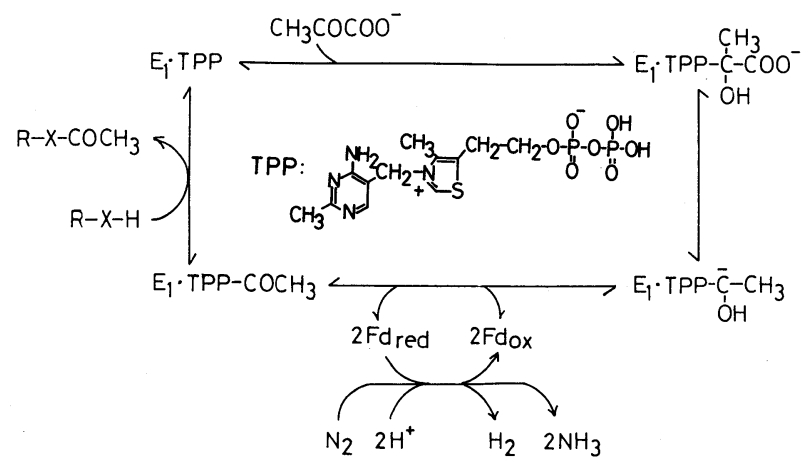

Scheme 2

Table 6 The reduction of various substrates with the $\mathrm{PhCHO} / \mathrm{Et}_{3} \mathrm{~N} / 2$ system.

\begin{tabular}{|c|c|c|c|c|}
\hline Substrate & E1/2[V.S.SCE) & Product & \multicolumn{2}{|c|}{$\% \begin{array}{c}\mathrm{PhCOOMe} \\
\%\end{array}$} \\
\hline & & & & 87 \\
\hline & $\left(\begin{array}{c}-0.36 \\
\mathrm{H}_{2} \mathrm{O}, \mathrm{pH} 8.4\end{array}\right)$ & & 83 & 84 \\
\hline 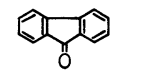 & $\begin{array}{cc}-0.96 & ;-1.13 \\
(\text { EtOH(25\%), } & \text { pH7.8) }\end{array}$ & None & 0 & 0 \\
\hline$\underset{0}{\mathrm{PhCCH}}=\underset{\|\|}{\mathrm{C}} \mathrm{CH}$ & $\left(\begin{array}{cc}-0.44 & ;-1.5 \\
(E t O H(50 \%), & p H 7.2]\end{array}\right.$ & $\underset{0}{\left(\mathrm{PhCCH}_{2} \mathrm{CH}_{2}\right.}$ & 95 & 91 \\
\hline $\mathrm{PhNO}_{2}$ & $\left(\begin{array}{l}-0.776 \\
\mathrm{MeOH}(80 \%)\end{array}\right) \mathrm{PhN}$ & $\begin{array}{r}\mathrm{PhNH}_{2} \\
\mathrm{~N}(\mathrm{OH}) \mathrm{COPh}\end{array}$ & $\begin{array}{l}25 \\
22\end{array}$ & 60 \\
\hline
\end{tabular}

PhCHO : Subst: $\mathrm{Et}_{3} \mathrm{~N}: \mathbb{S}_{\mathrm{S}^{ \pm}}^{\mathrm{N} \cdot \mathrm{CH}_{2} \mathrm{Ph}}=6: 4: 5: 1, \mathrm{MeOH}$, r.t. $20 \mathrm{~h}$ 

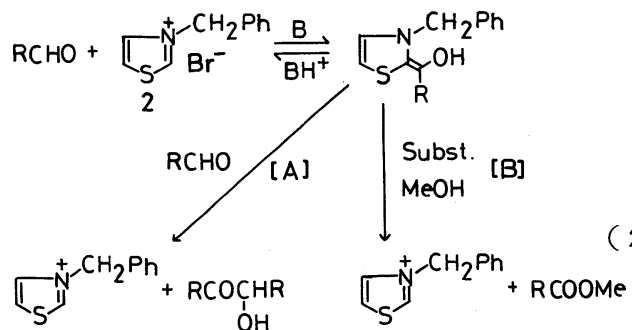

+ Reduced subst

られている (式 27-A)。中間に生じる活性アルデヒドは, その構造がスキーム 2 に示寸活性アルデヒドに似ている ことから，筆者らはまずこのベンゾイン縮合の代わりに， 諸種の電子受容性基質との反応を行い, 活性アルデヒド の還元作用を調べてみた ${ }^{36)}$ 。ベンズアルデヒド， 2，お よび基質をメタノールに溶かし, 脱気して酸素を除き, ついで Ar下でトリエ.チルアミンを加え, 室温で 20 時 間擐抖するという操作で反応を行う。ベンズアルデヒド: 基質：トリエチルアミン：2 のモル比を， $6: 4: 5: 1$ で 行った結果を表 6 にまとめて示す。還元電位 $\left(\mathrm{E}_{1 / 2}\right.$ vs. $\mathrm{SCE}$ ，プロトン性溶媒）が $-0.7 \sim-0.8 \mathrm{~V}$ より正の基質 は触媒的に還元され, 還元生成物の生成量に対応寸る量 の安息香酸メチルが生成する。このことは, 酸化還元に 共役して, エステル化反応が起こることを意味し（式 27-B)，モデル系が生体系に似た反応形態をとることを 示している。反応は, 中間に生じた活性アルデヒドが基 質に電子を供与し，2-ベンゾイルチアゾリウム塩 (3) の生成を経てメタノールと反応し, エステルの生成とと もに, もとのチアジリウム塩が復元するといら経路で進 むと考えられる ${ }^{36)}$ 。ベンズアルデヒドの他に，2-フラン カルバルデヒドやへプタナールを用いたときにも, 反応

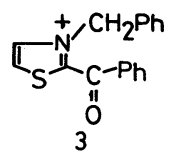

は同様に進行する。ニトロベンゼンはアニリンと $N$-ベ ンゾイルヒドロキシルアミンに，ニトロベンゼンの還元 中間体は, 表 7 に示すように, それぞれ対応する生成物 に還元される ${ }^{37)}$ 。ヒドラジベンゼンの還元はきわめて進 み難い。

このように，チアゾリウム塩 2 は塩基の存在下でアル デヒド類を活性化して電子受容性基質と酸化還元系を構 成し, アルデヒド類から基質へ電子を移寸電子伝達体と しての機能を発現することがわかった。次に, 活性アル デヒドが $4 \mathrm{Fe}-4 \mathrm{~S}$ クラスターを還元し得るかどうかを調 べるために, 先ほどと同じ要領で, メタノール中ベンズ アルデヒドと 2 をリリチルアミンの存在下で反応させ, その系に基質としてクラスター 1 を加え, 生成する安息 香酸メチルの量を追跡した ${ }^{38)}$ 。1 はメタノールに溶けな いので, 反応速度は遅いが, 1 の約 $1 / 2$ モル量の安息香 酸メチルが生成し, 生体系に似た反応が起こることを見

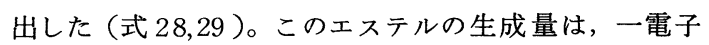

Enzyme system

$$
\underset{\mathrm{O}}{\mathrm{OPP}^{+}-\overline{\mathrm{C}}-\mathrm{CH}_{3}}+\mathrm{COA} \stackrel{\mathrm{Fd}^{\mathrm{Ox}}}{\longrightarrow} \mathrm{TPP}^{+}+\mathrm{CH}_{3} \mathrm{CO}-\mathrm{CoA} \text { (28) }
$$

Model system

$$
\underset{\substack{\mathrm{T}^{+}-\overline{\mathrm{C}}-\mathrm{Ph} \\ \mathrm{O} H}}{\mathrm{O}}+\mathrm{MeOH} \stackrel{\mathrm{Fe}_{4} \mathrm{~S}_{4}{ }^{2-}}{\longrightarrow} \mathrm{T}^{+}+\mathrm{PhCOOMe}
$$

還元により3-レベルのクラスターが生成していることを 示唆しており, メタノール系では, 前述したように, 水 素が生成する可能性がある。しかし, この条件下では水 素の生成を確認することはできなかった。そこで, 反応 系をより単純化するために, 活性アルデヒドの前駆体 4 を別法で合成し，4を(2:3) MeOH-HMPA 中トリエ チルアミンで処理して活性アルデヒドに導き,この系に, 1, ついでプロトン源としてベンゼンチオールを加えた ところ (式 30$),$ glc で検知できる程度であるが，水素

Table 7 The reduction of the nitrobenzene derivatives with the $\mathrm{PhCHO} / \mathrm{Et}{ }_{3} \mathrm{~N} / 2$ system ${ }^{\mathrm{a}}$.

\begin{tabular}{l|c|c|c|c|c}
\hline \multirow{2}{*}{ Substrate } & \multicolumn{5}{|c}{ Product, \% } \\
\cline { 2 - 6 } & $\mathrm{PhNH}_{2}$ & $\mathrm{PhN}(\mathrm{OH}) \mathrm{COPh}$ & $\mathrm{PhN}=\mathrm{NPh}$ & $\mathrm{PhNHNHPh}$ & $\mathrm{PhCOOMe}$ \\
\hline $\mathrm{PhNO}$ & 8 & 48 & 3 & 34 & $36(0.8)^{\mathrm{c})}$ \\
$\mathrm{PhNHOH}$ & 33 & 25 & 10 & 0 & $19(0.9)$ \\
$\mathrm{PhN}(\mathrm{OH}) \mathrm{COPh}$ & 8 & - & 0 & 0 & $10(2.0)$ \\
$\mathrm{PhN}=\mathrm{NPh}$ & 6 & 0 & - & 66 & $65(1.3)$ \\
\hline
\end{tabular}

a) $\mathrm{PhCHO}: \mathrm{Sub}_{\circ}: \mathrm{Et}_{3} \mathrm{~N}: 2=6: 4: 5: 1 . \mathrm{MeOH}, \mathrm{rt}, 20 \mathrm{~h}$.

b) Based on Sub. c) ( ) =Exp. mol/theo. mol. 


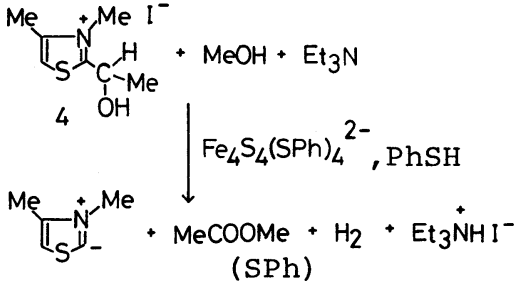

の生成を確認することができた ${ }^{39)}$ 。まだ水素の生成量は 少ないが，この反応はスキーム 2 の生体系の反応を化学 的に再現している点で意味があると考える。

\section{4. 水素の Heterolytic 切断による水素化反応}

ヒドロゲナーゼは水素を酸化的に切断してフェレドキ シンに電子を渡し, 水素を電子供与源とする電子伝達系 の構成に触媒として関与する (式 5 )。この酸化的切断 を行う活性部位は鉄-硫黄クラスターであることから ${ }^{40)}$, 合成鉄一硫黄クラスターを用いて水素の切断反応を研究 し，化学反応に応用することは意義がある。しかしなが ら, 現在のところ, まだ水素を酸化的に切断する触媒系 は得られていない。ここでは, 生体機能から離れて, 合 成 $4 \mathrm{Fe}-4 \mathrm{~S}$ クラスターを用いて行った水素の切断反応と その反応系を水素化反応に応用した結果について述べる ことにする。

以前に, クラスター $1^{41)}$ およびシリカゲル担持 $\mathrm{Fe}_{4} \mathrm{~S}_{4}$ クラスター ${ }^{42)}$ は, いずれも水素と反応しないことが報告 された。一方, 生体内における水素の切断機構として, 酸化型鉄-硫黄クラスターと塩基の作用による heterolytic 切断機構が提唱された（図 5 $)^{41)}$ 。しかし，クラスタ ー 1 を酸化して 1-状態に導くことは現在のところ困難で ある。そこで, 筆者らは $\mathrm{Fe}_{4} \mathrm{~S}_{4}$ 中心の末端サイトを操作し て水素を切断することにした ${ }^{43)}$ 。すなわち, ラビルな配 位子をむつクラスター（5）（(式 8) の反応で合成）を用 い, 常圧の水素の雾囲気下, $0^{\circ} \mathrm{C}$ のエーテル中で $\mathrm{PhLi}$ と反応させた。その結果, $\mathrm{PhLi} / 5$ モル比が $4 \sim 5$ 付近以 上で水素の吸収が観察されること, また水素の吸収が終 ったのち, その反応系を1,2-ジブロモェタン, ついで酸

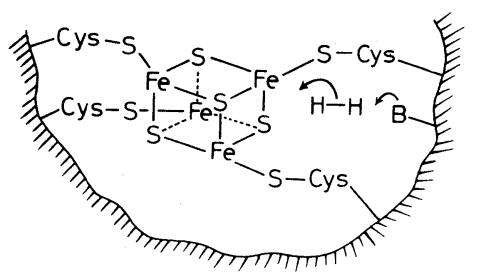

Fig. 5

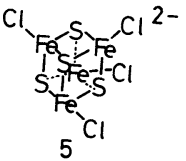

Table 8 The amounts of hydrogen absorbed and benzene produced in the reaction of the PhLi-treated cluster 5 with hydrogen ${ }^{a}$.

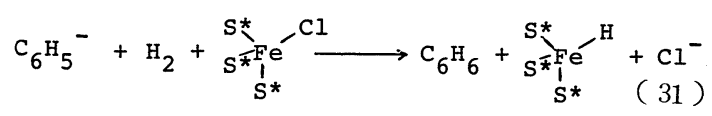

\begin{tabular}{c|c|c}
\hline \multirow{2}{*}{$\begin{array}{c}\text { Molar ratio } \\
\mathrm{PhLi} / 5\end{array}$} & \multicolumn{2}{|c}{$\mathrm{mol}^{-} \mathrm{Fe}_{4} \mathrm{~S}_{4}$ unit } \\
\cline { 2 - 3 } & $\mathrm{H}_{2}$ & $\mathrm{C}_{6} \mathrm{H}_{6}$ \\
\hline $8: 1$ & 0.6 & 0.7 \\
$10: 1$ & 1.2 & 1.4 \\
$12: 1$ & 2.4 & 2.7 \\
\hline
\end{tabular}

a) $0^{\circ} \mathrm{C}, \mathrm{Et}_{2} \mathrm{O}$.

素で酸化し，ベンゼンの生成量を定量したところ，水素 の吸収量とほぼ対応量のベンゼンが生成していることを 見出した (表 8) ${ }^{44)}$ 。これらの結果は水素が heterolytic に切断されていることを示唆し, 生じたヒドリドは恐ら く鉄-ヒドリド錯体として存在すると考えられる(式 31)。 この反応において, $\mathrm{Fe}_{4} \mathrm{~S}_{4}$ 中心は $\mathrm{Ph}$-により還元されてい るので, (式 26 ）の反応で試みたように，このヒドリド 中間体をオレフィン類の水素化反応に応用した ${ }^{44)}$ 。一例 として，オクテン類の水素化反応の結果を表 9 に示す。 水素化收率は $\mathrm{PhLi} / 5$ のモル比に依存し, モル比が 4 付 近では末端オレフィンのみが水素化され, 内部オレフィ ンの水素化は起こり難いことがわかる。したがって，1デセンと 2-または 3-オクテンの (1:1) 混合系の水素化 をこの条件下で行うと，1-デセンからデカンへの水素化 のみが触媒的に起こり,2-または 3-オクテンは反応せず に残る。 5 の代わりに，塩化鉄（III）を用いた場合には, このような選択性は現われないので, この基質選択性は $4 \mathrm{Fe}-4 \mathrm{~S}$ クラスターの特徵であると考えられる。モル比 を 8〜12 付近に上げると, 末端および内部オレフィンの 両方とも水素化される。1-オクテンからオクタンへの水 桑化は，モル比が 8 のときに, $\mathrm{Fe}_{4} \mathrm{~S}_{4}$ 単位当たり約 207 回サイクルすることを見出している。また, 溶媒は水素 化に著しい影響を与える。(1:1.5) HMPA-エーテル混 合溶媒を用いると, $\mathrm{PhLi} / 5$ のモル比が高いところでも, 内部オレフィンの水素化は起こり難くなり, 末端オレフ ィンのみが選択的に水素化される。このように, PhLiに よる処理および溶媒の作用は $\mathrm{Fe}_{4} \mathrm{~S}_{4}$ 中心の末端サイトで 
Table 9 Catalytic hydrogenation of octenes using the $\mathrm{PhLi} / 5 / \mathrm{H}_{2}$ system ${ }^{\mathrm{a}}$.

\begin{tabular}{|c|c|c|c|c|}
\hline \multirow{2}{*}{ Octenes } & \multicolumn{3}{|c|}{ Yield $\left.(\%)^{b}\right)$} & \multirow[b]{2}{*}{ Other octenes } \\
\hline & $\mathrm{PhLi} / 5$ & Octane & 2-Octene $\mathrm{e}^{\mathrm{c})}$ & \\
\hline \multirow[t]{2}{*}{ trans-1-octene } & $4: 1$ & 49 & 15 & 35 \\
\hline & $8: 1$ & 92 & 0 & Trace \\
\hline \multirow[t]{2}{*}{ trans-2-octene } & $4: 1$ & 3 & 91 & 0 \\
\hline & $8: 1$ & 52 & 27 & 17 \\
\hline \multirow[t]{2}{*}{ trans-3-octene } & $4: 1$ & 0 & 0 & 95 \\
\hline & $8: 1$ & 78 & 5 & 15 \\
\hline trans-4-octene & $8: 1$ & 71 & 3 & 17 \\
\hline
\end{tabular}

の水素化反応を制御する。以上, 水素の切断反応と水素化 反応について述べた。生体系のように，水素の酸化的切 断を行う鉄一硫黄クラスターおよび反応系の設計は今後 の課題である。

\section{5. おわりに}

フェレドキシンモデルおよびそれに関連する生体機能 材料を化学反応に応用した筆者らの仕事を紹介した。前 述したように, 合成 $4 \mathrm{Fe}-4 \mathrm{~S}$ クラスターは諸種の酸化還 元反応に電子伝達体あるいは反応サイトとして作用し, 酸化と還元の分離, 電子の蓄積と放出, 末端サイトの反 応性の制御などの興味ある機能を発現する。これらの機 能を利用すると, さらに多くの酸化還元采を構築するこ とが可能であろう。しかしながら，ここで用いた $4 \mathrm{Fe}-$ $4 \mathrm{~S}$ クラスターは $2-\rightleftharpoons 3-\rightleftharpoons 4-の$ 変換に基づく電子伝達作 用を示しており，1ーレベルの酸化状態をとらない。この ことは基質の酸化を目的とする電子伝達系の構成を不利 にしている。また, 還元電位が低いことも電子供与体の 使用範囲を制限する原因となっている。今後, $4 \mathrm{Fe}-4 \mathrm{~S}$ クラスターを反応に利用していく場合に, これらの問題 点を解決することが望まれる。さらに， $4 \mathrm{Fe}-4 \mathrm{~S}$ クラス ターは反応サイトとしてよりむしろ電子伝達体としての 機能が優れているので, クラスターを電子伝達体として 用い, 別に反応サイトを設定した多元システムを構成す ることが望まれるであろう。これらのことを実現するこ とにより，4Fe-4S クラスターの化学反応への応用範囲 は広がるものと思われる。

ここで述べた䇥者らの研究は, それぞれの文献中にあ る協同研究者の努力によるものであり, ここに改めて謝 意を表する。

(昭和 59 年 9 月 29 日受理)

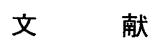

1) R. A. Sheldon, J. K. Kochi, "Metal-Catalyzed
Oxidations of Organic Compounds", (1981) Academic Press.

2) J.K. Kochi, "Organometallic Mechanism and Catalysis", (1978) Academic Press ; J.

Halpern, "Fundamental Research in Homogeneous Catalysis", (M. Tsutsui ed.), p. 25 (1979) Plenum Press ; R. D. Cannon, "Electron Transfer Reaction", p. 26 and p. 137 (1980) Butterworths.

3) M. Chanon, M. L. Tobe, Angerw. Chem. Int. Ed. Engl., 21, 1 (1982) ; J. F. Bunnett, Acc. Chem. Res., 11, 413 (1978) ; J. M. Saveant, ibid., 13, 323 (1980) ; M. Chanon, Bull. Soc. Chim. Fr. II-197 (1982)

4) D. G. Whitten, Acc. Chem. Res., 13, 83 (1980); 日本化学会編, 有機光化学の新展開, 化 学総説, No. 33 (1982) 学会出版センター; M. Julliard, M. Chanon, Chem. Rev., 83, 425 (1983) ; 長，哲郎，庄野達哉，本多健一，Electroorganic Chemistry, 化学增刊 86 (1980) 化学 同人; A. Buet, A. Darchen, C. Moinet, J. Chem. Soc., Chem. Commun., 1979, 447; R. Scheffold, M. Dike, S. Dike, T. Herold, L. Walder, J. Am. Chem. Soc., 102, 3642 (1980)

5） 日本化学会編, バイオミメティック・ケミストリ 一, 化学総説, No.35 (1982) 学会出版センター

6) J.C. Rabinowitz, "Bioinorganic Chemistry" (R.F. Gould ed.), p.322 (1971) Am. Chem. Soc.

7) B. A. Averill, T.Herskovitz, R.H.Holm, J. A. Ibers, J. Am. Chem. Soc., 95, 3523 (1973)

8) L. Que, Jr., M.A. Bobrik, J. A. Ibers, R. H. Holm, ibid., 96, 4168 (1974); G. R. Dukes, R. H. Holm, ibid., 97, 528 (1975)

9) R.W. Johnson, R.H. Holm, ibid., 100. 5338 (1978)

10) H. L.Carrell, J.P. Glusker, R. Tob, T.C. Bruice, ibid., 99, 3683 (1977) ; M. A. Bobrik, K.O. Hodgson, R.H.Holm, Inorg. Chem., 
16, 1851 (1977) ; M. A. Bobrik, E. J. Laskowski, R. W. Johnson, W. O. Gillum, J. M. Berg, K. O. Hodgson, R. H. Holm, ibid., 17, 1402 (1978)

11) R. H. Holm, B. A. Averill, T.Herskovitz, R. B. Frankel, H. B. Gray, O. Siiman, F. J. Grunthaner, J. Am. Chem. Soc., 96, 2644 (1974) ; E. J. Laskowski, R. B. Frankel, W. O. Gillum, G. C.Papaefthymiou, J. Renaud, J. A. Ibers, R. H. Holm, ibid., 100, 5322 (1978)

12) B. V.DePamphilis, B.A. Averill, T. Herskovitz, L. Que, Jr., R. H. Holm, ibid., 96, 4159 (1974)

13) C.L. Hill, J. Renaud, R. H. Holm, L.E. Mortenson, ibid., 99, 2549 (1977)

14) R.E. Johnson, G. C.Papaefthymiou, R. B. Frankel, R. H. Holm, ibid., 105, 7280 (1983)

15) N. Ueyama, T.Terakawa, M. Nakata, A. Nakamura, ibid., 105, 7098 (1983)

16) H.Inoue, N. Fujimoto, E. Imoto, 26th International Congress of Pure and Applied Chemistry, Session 1, p.34 (1977)

17）未発表

18）井上博夫, 藤本典裕, 井本英二, 日本化学会第 36 春季年会講演予講集，II, p. 822 (1977)

19) G. N. Schrauzer, G. W. Kiefer, K. Tano, P. A. Doemeny, J. Am. Chem. Soc., 96, 641(1974); R.W.Lane, A. G. Wedd, W.O. Gillum, E. J. Laskowski, R. H. Holm, R.B. Frankel, G.C. Papaefthymiou, ibid., 99, 2350 (1977)

20) E. E. Van Tamelen, J. A. Gladysz, C.R. Brûlet, ibid., 96, 3020 (1974)

21) M. Tezuka, T. Yajima, A.Tsuchiya, Y. Matsumoto, Y. Uchida, M. Hidai, ibid., 104, 6834 (1982)

22) T.Mashino, T.Nagano, M. Hirobe, Tetrahedron Lett., 24, 5113 (1983)

23) K. Tanaka, M. Tanaka, T. Tanaka, Chem. Lett., 1981, 895

24) H. Inoue, N. Fujimoto, E. Imoto, J. Chem. Soc., Chem. Commun., 1977, 412

25) H. O. House, Acc. Chem. Res., 9, 59 (1976)
26) E. C. Ashby, J. D. Buhler, I. G. Lopp, T. L. Wiesemann, J.S. Bowers, J. T. Laemmle, J. Am. Chem. Soc., 98, 6561 (1976); E. C. Ashby, T.L. Wiesemann, ibid., 100, 189 (1978)

27) H. Inoue, M. Suzuki, N. Fujimoto, J. Org. Chem., 44, 1722 (1979)

28) J. H. Stocker, R. M. Jenevein, D. H. Kern, ibid., 34, 2810 (1969)

29) H. Inoue, M. Suzuki, T. Nagata, 25th Symposium on Organomet. Chem. Japan, Abst. 75 (1978)

30) G. N. Schrauzer, T.D. Guth, J. Am. Chem. Soc., 98, 3508 (1976)

31) G. Christou, R. V. Hageman, R. H. Holm, ibid., 102, 7600 (1980)

32) K. Tano, G. N. Schrauzer, ibid., 97, 5404 (1975)

33）井上博夫，佐藤 誠，第 10 回酵素類似様機能を もつ有機化学反応の研究会, 講演要旨集, p. 21 (1983)

34) H. Inoue, M. Sato, J. Chem. Soc., Chem. Commun., 1982, 1014

35) H. R. Mahler, E. H. Cordes, "Biological Chemistry", p. 438 (1966) Harper \& Row.

36) H. Inoue, K. Higashiura, J. Chem. Soc., Chem. Commun., 1980, 549

37）東浦邦彦, 井上博夫, 日本化学会第 41 春季年会, 請演予稿集 II , p. 893 (1980)

38）東浦邦彦, 井上博夫, 第 8 回酵素類似様機能をも つ有機化学反応の研究会, 講演要旨集, p. 20 (1981)

39）未発表

40) R.H.Holm, Acc. Chem. Res., 10, 427 (1977)

41) B.A. Averill, W.H. Orme-Johnson, ibid., 100, 5234 (1978)

42) R. G. Bowman, R. L. Burwell, Jr., ibid., 101, 2877 (1979)

43) H. Inoue, M. Suzuki, J. Chem. Soc., Chem. Commun., 1980, 817

44) H. Inoue, M.Sato, ibid., 1983, 983 